\title{
Purification and Characterization of 6-Phosphogluconate Dehydrogenase from Phormidium sp.
}

\author{
Yoshihiro Sawa, Kanji SuzuKi and Hideo OCHIAI \\ Laboratory of Biochemistry, College of Agriculture, Shimane University, \\ Nishikawazu-1060, Matsue, Shimane 690, Japan
}

Received November 26, 1984

\begin{abstract}
A procedure for the purification of 6-phosphogluconate dehydrogenase from the cyanobacterium Phormidium sp. is described. The molecular weight of the native enzyme was 104,000 by gel filtration, and SDS-polyacrylamide gel electrophoresis showed that the enzyme consisted of two subunits with an identical molecular weight of 52,000. The optimum $\mathrm{pH}$ of the reaction was 8.0. The $\mathrm{Km}$ values for 6-phosphogluconate and NADP were $3.6 \times 10^{-5} \mathrm{M}$ and $1.3 \times 10^{-5} \mathrm{M}$, respectively. The enzyme showed no $\mathrm{Mg}^{2+}$ requirement for the activity, but was activated by $\mathrm{Mn}^{2+}$ and $\mathrm{Ca}^{2+}$. The enzyme was inhibited by sulfhydryl reagents, indicating that a sulfhydryl group may be involved in the active site of the enzyme. The enzyme was also inhibited by $\mathrm{NADPH}_{2}$, ATP, and the intermediates formed during photosynthesis. The substrate 6-phosphogluconate and cofactor NADP partially protected the enzyme from inactivation. The enzyme had enzymological and physicochemical properties similar to enzymes isolated from other sources.
\end{abstract}

The enzyme 6-phosphogluconate dehydrogenase [6PGDH; EC 1.1.1.44, 6-phospho-Dgluconate: NADP 2-oxidoreductase(decarboxylating)] has been extensively studied and isolated from a number of sources because of its key role in the pentose phosphate pathway. ${ }^{1 \sim 7)}$

In cyanobacteria sugar breakdown occurs exclusively via the oxidative pentose phosphate pathway, predominantly consisting of the same enzymes operating in the Calvin cycle, supplemented with two NADP-specific dehydrogenases, glucose 6-phosphate dehydrogenase (G6PDH; EC 1.1.1.49) and 6PGDH. ${ }^{8)}$ The metabolic links between photosynthetic and respiratory metabolism in cyanobacteria are therefore close. The formed $\mathrm{NADPH}_{2}$ can be used for ATP formation during the dark phase. ${ }^{8}$ For the oxidative pentose phosphate pathway, G6PDH is thought to be the key enzyme of regulation. Inhibition of cyanobacterial G6PDH by $\mathrm{NADPH}_{2}$, ATP, glutamine, and ribulose 1,5-bisphosphate (RUBP), as well as some enzymatic properties have been reported. ${ }^{9 \sim 11)}$ However, little is known of the cyanobacterial 6PGDH.

We describe here a purification procedure and the characterization of the enzymatic, physical, and chemical properties of 6PGDH from Phormidium sp. These studies permit elucidation of the mechanisms that regulate 6PGDH activity in vivo.

\section{MATERIALS AND METHODS}

Biological material and culture methods. The filamentous cyanobacterium, Phormidium sp., isolated from Matsue hot springs, was cultured photoautotrophycally at $47^{\circ} \mathrm{C}$ as described previously. ${ }^{12)}$ Cells were harvested in the late logarithmic phase by filtration and washed with distilled water.

Enzyme assays. The 6PGDH activity was measured at $340 \mathrm{~nm}$ in a Shimadzu model UV 240 spectrophotometer with a thermostated cuvette holder maintained at $43^{\circ} \mathrm{C}$. The standard assay mixture contained the following components in a final volume of $1.0 \mathrm{ml}: 100 \mathrm{~mm}$ Tris- $\mathrm{HCl}$ buffer, $\mathrm{pH} 8.2 ; 0.5 \mathrm{~mm}$ sodium 6-phosphogluconate (6PG);

Abbreviation: PCMB, $p$-chloromercuribenzoic acid; NEM, $N$-ethylmaleimide; DTNB, 5,5'-dithio-bis(2-nitrobenzoic acid). 
and $0.5 \mathrm{~mm}$ NADP. The reaction was initiated by the addition of $6 \mathrm{PG}$ and followed by the rate of $\mathrm{NADPH}_{2}$ formation. The $\mathrm{Km}$ for the substrate was measured under saturating conditions of the co-enzymes $(0.5 \mathrm{~mm})$. The $\mathrm{Km}$ for the co-enzyme was measured under saturating conditions of the substrate $(0.5 \mathrm{~mm})$. Activities were calculated from the initial slopes and the unit of activity was defined as the amount of enzyme catalyzing the reduction of $1 \mu \mathrm{mol}$ of $\mathrm{NADP} / \mathrm{min}$. Specific activity was expressed as enzyme units per mg of protein. Protein was estimated by the method of Lowry et al. with bovine serum albumin as a standard. ${ }^{13)}$

Preparation of blue-Sepharose $4 \mathrm{~B}$. Blue-Sepharose was prepared by the method of Henys and DeMoor. ${ }^{14)}$ Sepharose $4 \mathrm{~B}$ agarose gel $(150 \mathrm{ml})$ was washed twice with distilled water and filtered on a Buchner funnel. After the last filtration, $2 \mathrm{~g}$ of $\mathrm{Na}_{2} \mathrm{CO}_{3}$ in $50 \mathrm{ml}$ of water were combined with $1 \mathrm{~g}$ of Cibacron F3GA dye in $50 \mathrm{ml}$ of water to give $100 \mathrm{ml}$ of solution; to this was added the washed Sepharose 4B with mild agitation. The mixture was left at $43^{\circ} \mathrm{C}$ for $48 \mathrm{hr}$ with occasional agitation. The gel was then washed extensively with water and stored in distilled water at $4^{\circ} \mathrm{C}$ until use.

Electrophoresis. Analytical polyacrylamide gel electrophoresis was done by the method of Davis ${ }^{15)}$ in a column of $7.5 \%$ polyacrylamide gel with $\mathrm{pH} 9$ buffer system, with a current of $4 \mathrm{~mA}$ per column. Gels were stained with Amido Black 10B. To find bands with 6PGDH activity, gels were also stained with the following mixture: $0.5 \mathrm{~mm}$ 6PG, $0.5 \mathrm{~mm}$ NADP, $65 \mu \mathrm{M}$ phenazine methosulfate, $35 \mu \mathrm{M}$ nitroblue tetrazolium, and $50 \mathrm{~mm}$ Tris- $\mathrm{HCl}$ buffer, $\mathrm{pH} 8.2$. Gels were immersed in this solution and incubated at $45^{\circ} \mathrm{C}$ in the dark. SDS polyacrylamide gel electrophoresis was done by the method of Laemmli. ${ }^{16)}$ Gels were stained with Coomassie Brilliant Blue. Cytochrome $c$ monomer $(12,400)$, dimer $(24,800)$, trimer $(37,200)$, tetramer $(49,600)$, and hexamer $(74,400)$ were used as standards.

Measurement of molecular weight by gel filtration. The molecular weight of 6PGDH was estimated by descending chromatography using a Sephadex G-150 column $(1.8 \times$ $114 \mathrm{~cm}$ ), equilibrated with $50 \mathrm{~mm}$ Tris- $\mathrm{HCl}, \mathrm{pH} 7.5$, containing $0.1 \mathrm{M} \mathrm{NaCl}$, at a flow rate of $4.5 \mathrm{ml}$ per hr column was calibrated with the following proteins of known molecular weights: cytochrome $c(12,500)$, chymotrypsinogen $A(25,000)$, egg albumin $(45,000)$, bovine serum albumin $(67,000)$, and alcohol dehydrogenase $(148,000)$.

Chemicals. 6-Phosphogluconate, NADP, glucose 6phosphate, ATP, ADP, AMP, alcohol dehydrogenase, and molecular weight standards for SDS gel electrophoresis were purchased from Oriental Yeast Co. RUBP, ribulose 5-phosphate, cytochrome $c$, and chymotrypsinogen A were obtained from the Sigma Chemical Co. DEAE-cellulose was obtained from Serva. Hydroxy- apatite was purchased from Seikagaku Kogyo Co. DEAE-Toyopearl was a product of Toyo Soda Co. All other chemicals were reagent grade.

\section{RESULTS}

\section{Enzyme purification}

All steps of the purification procedure were done at $4{ }^{\circ} \mathrm{C}$. Unless otherwise specified, Tris$\mathrm{HCl}$ buffer was used. All the buffer solutions contained $1 \mathrm{~mm}$ EDTA and $0.05 \%$ 2-mercaptoethanol, and were adjusted to $\mathrm{pH}$ 7.5.

\section{Step I}

Extraction. About $80 \mathrm{~g}$ of wet algal cells were suspended in 5 volumes of $0.1 \mathrm{M}$ buffer and ground in a mortar with $40 \mathrm{~g}$ of aluminum oxide powder. Extraction was completed by ultrasonic treatment (in a Tomy Seiko UR$200 \mathrm{P}$ for $5 \mathrm{~min}$ at full power). After centrifugation at $15,900 \mathrm{~g} 15 \mathrm{~min}$, solid ammonium sulfate was added to the supernatant solution and the precipitates formed at 0.70 saturation were collected by centrifugation, dissolved in a minimal volume $(45 \mathrm{ml})$ of $0.1 \mathrm{M}$ buffer, and dialyzed against $10 \mathrm{~mm}$ buffer overnight.

\section{Step II}

DEAE-cellulose column chromatography. The dialyzed solution was then put on a DEAE-cellulose column $(6 \times 15 \mathrm{~cm})$ equilibrated with $10 \mathrm{~mm}$ buffer containing $80 \mathrm{~mm}$ $\mathrm{NaCl}$. The column was then washed with the same buffer until the absorbance at $280 \mathrm{~nm}$ was less than 0.1 . The enzyme was eluted with $10 \mathrm{~mm}$ buffer containing $160 \mathrm{~mm} \mathrm{NaCl}$. Active fractions $(1830 \mathrm{ml})$ were collected, and dialyzed against $50 \mathrm{~mm}$ buffer overnight.

\section{Step III}

Blue-Sepharose column chromatography. The dialyzed solution was then put on a BlueSepharose column $(3 \times 14 \mathrm{~cm})$ equilibrated with $50 \mathrm{~mm}$ buffer. The column was then washed with the same buffer until the blue color derived from phycobilin-protein disappeared. The enzyme was eluted with $50 \mathrm{~mm}$ buffer containing $1 \mathrm{~mm}$ NADP. Active fractions $(225 \mathrm{ml})$ were pooled and then promptly con- 
Table I. Purification Steps of Phormidium 6-Phosphogluconate Dehydrogenase

\begin{tabular}{lccccc}
\hline \multicolumn{1}{c}{ Steps } & $\begin{array}{c}\text { Total } \\
\text { protein } \\
(\mathrm{mg})\end{array}$ & $\begin{array}{c}\text { Total } \\
\text { activity } \\
\text { (units) }\end{array}$ & $\begin{array}{c}\text { Specific } \\
\text { activity } \\
\text { (units/mg) }\end{array}$ & Purity & Yield (\%) \\
\hline Crude & 2534.0 & 115.5 & 0.046 & 1 & 1.52 \\
DEAE-cellulose & 1406.6 & 98.9 & 0.070 & 9.52 & 85.6 \\
Blue gel & 146.8 & 64.4 & 0.438 & 53.3 & 39.8 \\
DEAE-Toyopearl & 18.8 & 45.8 & 2.45 & 156.9 & 11.2 \\
Hydroxyapatite & 1.78 & 12.9 & 3.22 & 826.9 & 4.4 \\
Sephadex G-150 & 0.13 & 5.1 & 38.0 & & \\
\hline
\end{tabular}

centrated in a Toyo ultrafiltration cell (model UHP-62) equipped with a UK-10 membrane.

\section{Step IV}

DEAE-Toyopearl column chromatography. The enzyme solution $(25 \mathrm{ml})$ from step III was put on a DEAE-Toyopearl column $(3 \times 14 \mathrm{~cm})$ equilibrated with $50 \mathrm{~mm}$ buffer containing $80 \mathrm{~mm} \mathrm{NaCl}$. The enzyme was eluted with $50 \mathrm{~mm}$ buffer containing $160 \mathrm{~mm} \mathrm{NaCl}$. Active fractions $(280 \mathrm{ml})$ were collected and then concentrated as above. The enzyme solution was then dialyzed against $5 \mathrm{~mm}$ potassium phosphate buffer (K-phosphate), pH 7.5 overnight.

\section{Step V}

Hydroxyapatite column chromatography. The dialyzed solution was put on a hydroxyapatite column $(1.6 \times 20 \mathrm{~cm})$ equilibrated with $5 \mathrm{~mm} \mathrm{~K}$-phosphate. The $6 \mathrm{PGDH}$ activity passed through the column unadsorbed. Active fractions were collected and then concentrated in Toyo ultrafiltration cell.

\section{Step VI}

Sephadex G-150 column chromatography. The enzyme solution from step $\mathrm{V}$ was put on a Sephadex G-150 column $(1.8 \times 114 \mathrm{~cm})$ equilibrated with $50 \mathrm{~mm}$ buffer. The active fraction $(70 \mathrm{ml})$ was used as the purified enzyme preparation.

The results of a typical purification scheme are summarized in Table I. By this procedure, the enzyme was obtained in $4.4 \%$ yield with an overall purification of about 830 -fold and a specific activity of 38 .

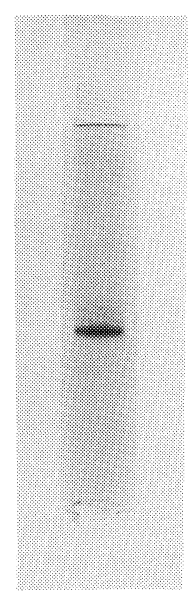

Fig. 1. Polyacrylamide Gel Electrophoresis of the Purified 6-Phosphogluconate Dehydrogenase.

Electrophoresis was done using a $7.5 \%$ gel as described in Materials And Methods. Protein $(30 \mu \mathrm{g})$ was stained with Amido Black.

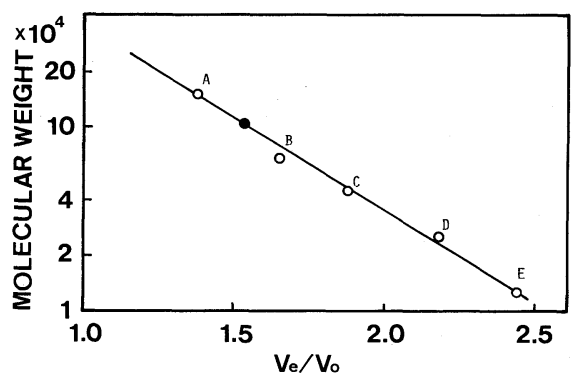

FIG. 2. Molecular Weight Measurement by Gel Filtration.

A, alcohol dehydrogenase $(148,000)$; B, bovine serum albumin $(67,000)$; C, egg albumin $(45,000)$; D, chymotrypsinogen $A(25,000)$; E, cytochrome $c(12,500)$.

Purified 6PGDH was homogeneous by polyacrylamide gel electrophoresis as shown in Fig. 1. The activity staining also showed a 


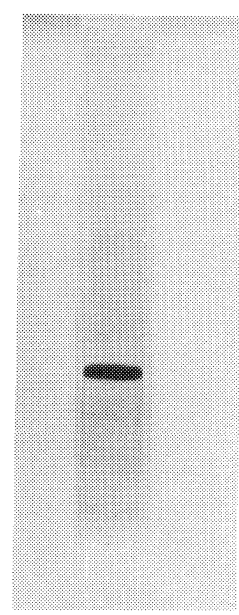

(A)

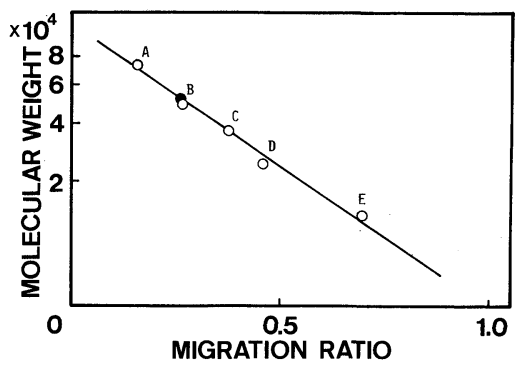

(B)

FIG. 3. SDS-Polyacrylamide gel Electrophoresis and Molecular Weight Measurement of the Purified 6Phosphogluconate Dehydrogenase.

Samples $(10 \mu \mathrm{g})$ were put on a $12.5 \%$ acrylamide gel and electrophoresed as described under MATERIALS AND METHODS.

A, cytochrome $c$ hexamer $(74,400)$; B, cytochrome $c$ tetramer $(49,600)$; $\mathrm{C}$, cytochrome $c$ trimer $(37,200)$; D, cytochrome $c$ dimer $(24,800)$; E, cytochrome $c$ monomer $(12,400)$.

single purple band at the same position as that of the protein band.

\section{Molecular weight}

The molecular weight of the enzyme was estimated as 104,000 by Sephadex G-150 gel filtration as shown in Fig. 2. SDS polyacrylamide gel electrophoresis gave a single protein band (Fig. 3A) corresponding to a molecular weight of approximately 52,000 as shown in Fig. 3B.
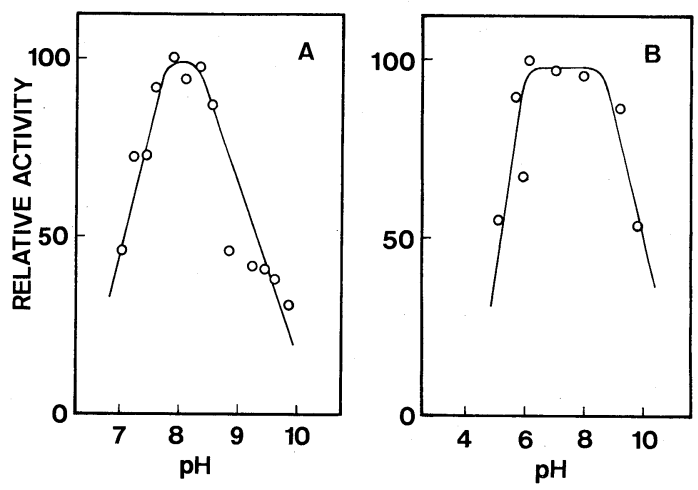

FIG. 4. Effects of pH on Activity and Stability of the Enzyme.

A: Effects of $\mathrm{pH}$ on the activity. The enzyme reaction was done at various $\mathrm{pHs}(7 \sim 9.6)$. Buffer used was $0.2 \mathrm{M}$ Tris$\mathrm{HCl}$.

B: Effects of $\mathrm{pH}$ on the stability. The enzyme solution was kept at $50^{\circ} \mathrm{C}$ for $5 \mathrm{~min}$ in various buffers with $\mathrm{pH}$ ranging from 4 to 9.6 , and the remaining activity was assayed. Buffers used were: acetate ( $\mathrm{pH} 4 \sim 6)$, Tris-maleate $(\mathrm{pH}$ $5.6 \sim 7.8)$ and Tris- $\mathrm{HCl}(\mathrm{pH} 7.8 \sim 9.6)$.

Table II. Effects of Metal Ions on the Activity of 6-Phosphogluconate Dehydrogenase

The mixture of $0.05 \mathrm{ml}$ of $10 \mathrm{~mm}$ NADP, $0.4 \mathrm{ml}$ of $0.25 \mathrm{M}$ Tris- $\mathrm{HCl}$ buffer ( $\mathrm{pH} 8.2), 0.05 \mathrm{ml}$ of the enzyme solution $(15.3 \mathrm{~m}$ units), $0.35 \mathrm{ml}$ of distilled water, and $0.1 \mathrm{ml}$ of $10 \mathrm{~mm}$ salts was preincubated at $43^{\circ} \mathrm{C}$ for $10 \mathrm{~min}$, and then to the mixture was added $0.05 \mathrm{ml}$ of $10 \mathrm{~mm}$ 6-phosphogluconate. The reaction was assayed under the standard conditions.

\begin{tabular}{lcc}
\hline Compounds & $\begin{array}{c}\text { Conc. } \\
\text { (mM) }\end{array}$ & $\begin{array}{c}\text { Relative } \\
\text { activity }\end{array}$ \\
\hline $\mathrm{CaCl}_{2}$ & 1.0 & 146.6 \\
$\mathrm{MnCl}_{2}$ & 1.0 & 142.1 \\
$\mathrm{MgCl}_{2}$ & 1.0 & 102.6 \\
$\mathrm{None}$ & - & 100.0 \\
$\mathrm{NH}_{4} \mathrm{Cl}$ & 1.0 & 98.7 \\
$\mathrm{NiCl}_{2}$ & 1.0 & 68.1 \\
$\mathrm{BaCl}_{2}$ & 1.0 & 61.7 \\
$\mathrm{CoCl}_{2}$ & 1.0 & 47.7 \\
$\mathrm{CdCl}_{2}$ & 1.0 & 13.0 \\
$\mathrm{ZnCl}_{2}$ & 1.0 & 9.1 \\
$\mathrm{CuCl}_{2}$ & 1.0 & 6.0 \\
\hline
\end{tabular}

Effects of $p H$ on the enzyme activity and stability

The effects of $\mathrm{pH}$ on the enzyme activity are shown in Fig. 4. The enzyme showed a sharp $\mathrm{pH}$ optimum of 8 and was stable between $\mathrm{pH} 6$ and 9 . 
Table III. EfFects of Sulfhydryl Reagents on THE Activity of 6-Phosphogluconate DEHYDROGENASE

\begin{tabular}{|c|c|c|}
\hline Compounds & $\begin{array}{l}\text { Conc. } \\
(\mathrm{mm})\end{array}$ & $\begin{array}{l}\text { Relative } \\
\text { activity }\end{array}$ \\
\hline None & - & 100.0 \\
\hline \multirow[t]{2}{*}{ РCMB } & 0.2 & 60.1 \\
\hline & 0.1 & 83.5 \\
\hline \multirow[t]{2}{*}{$\mathrm{HgCl}_{2}$} & 0.5 & 0.0 \\
\hline & 0.1 & 95.0 \\
\hline \multirow[t]{2}{*}{ NEM } & 0.5 & 16.8 \\
\hline & 0.1 & 98.2 \\
\hline \multirow[t]{2}{*}{$\mathrm{ICH}_{2} \mathrm{COOH}$} & 0.5 & 97.7 \\
\hline & 0.1 & 100.1 \\
\hline DTNB & 0.1 & 87.2 \\
\hline
\end{tabular}

Table IV. EfFects of Metabolites on the Activity of 6-Phosphogluconate Dehydrogenase

\begin{tabular}{lcr}
\hline Compounds & $\begin{array}{c}\text { Conc. } \\
(\mathrm{mM})\end{array}$ & $\begin{array}{c}\text { Relative } \\
\text { activity }\end{array}$ \\
\hline None & & 100.0 \\
Glucose 6-P & 1 & 100.0 \\
Fructose 6-P & 1 & 95.0 \\
Fructose 1,6-P & 1 & 93.6 \\
Ribulose 5-P & 1 & 69.1 \\
Ribulose 1,5-P & 1 & 85.6 \\
ATP & 1 & 92.6 \\
ADP & 1 & 93.4 \\
AMP & 1 & 105.0 \\
NADPH & 0.1 & 78.2 \\
& 0.2 & 67.0 \\
\hline
\end{tabular}

\section{Effects of metal ions}

The effects of metal ions $(1.0 \mathrm{~mm})$ on the enzyme activity were investigated. As shown in Table II, the enzyme was activated by $\mathrm{Ca}^{2+}$ and $\mathrm{Mn}^{2+}$ up to about $140 \sim 150 \%$, but $\mathrm{Zn}^{2+}$, $\mathrm{Cu}^{2+}$, and $\mathrm{Cd}^{2+}$ strongly inhibited the activity.

\section{Km values}

The $\mathrm{Km}$ values for 6-phosphogluconate and NADP of the $6 \mathrm{PGDH}$ were $1.3 \times 10^{-5} \mathrm{M}$ and $3.6 \times 10^{-5} \mathrm{M}$, respectively. No activity was observed when NAD was substituted for NADP.

\section{Effects of sulfhydryl reagents}

The effects of some reagents on the enzyme

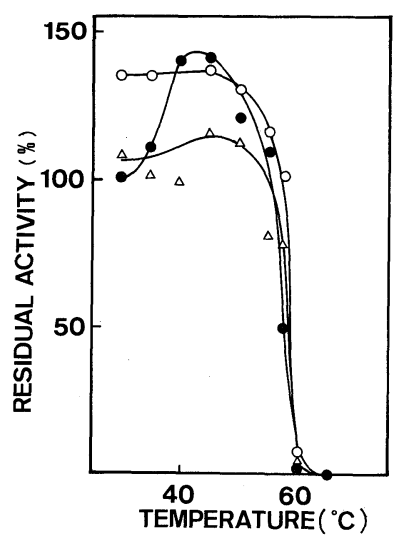

FIG. 5. Effects of Temperature on the Enzyme Activity.

The enzyme sample, $0.05 \mathrm{mg} / \mathrm{ml}$ in $0.05 \mathrm{M}$ Tris- $\mathrm{HCl}$ buffer, $\mathrm{pH} 7.5$, containing $0.05 \%$ 2-mercaptoethanol was incubated at various temperatures for $10 \mathrm{~min}$.

$\bigcirc-O$, no addition; $\bigcirc-\bigcirc,+0.3 \mathrm{~mm}$ NADP; $\triangle-\triangle$, $+0.3 \mathrm{~mm}$ 6-phosphogluconate.

activity are listed in Table III. The enzyme activity was inhibited by sulfhydryl reagents such as PCMB, NEM, DTNB, $\mathrm{Hg}^{2+}$ when these reagents were added in the reaction mixture, and the enzyme was protected from this inhibition by 2-mercaptoethanol.

\section{Effects of metabolites}

As shown in Table IV, the enzyme was inhibited by RUBP, ribulose 5-P, and $\mathrm{NADPH}_{2}$, and also weakly inhibited by fructose 6-P, fructose 1,6-P, ATP, and ADP.

\section{Thermal properties}

When the enzyme was incubated at various

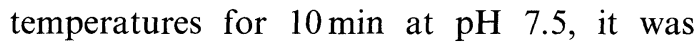
stable below $50^{\circ} \mathrm{C}$ and about $50 \%$ of the original activity was retained at $57^{\circ} \mathrm{C}$ (Fig.5). 6-Phosphogluconate and NADP gave only slight protection. On the other hand, the enzyme activity increased between $35^{\circ} \mathrm{C}$ to $50^{\circ} \mathrm{C}$ and the maximal activation $(140 \%)$ was at $40^{\circ} \mathrm{C}$. The enzyme activity was also increased up to $135 \%$ between $30^{\circ} \mathrm{C}$ to $50^{\circ} \mathrm{C}$ by the addition of $0.3 \mathrm{~mm}$ NADP.

\section{Effects of urea}

Figure 6 shows that the enzyme was stable in 


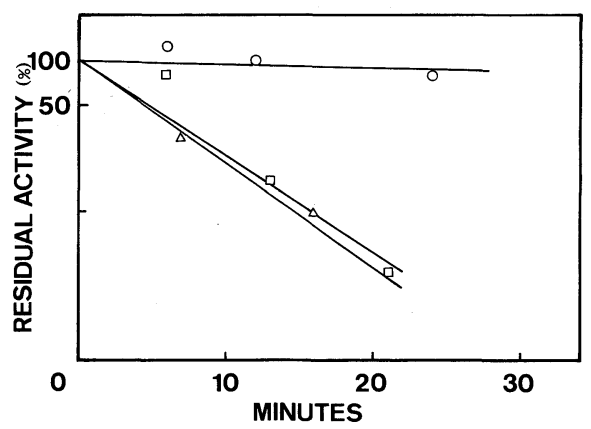

FIG. 6. Influence of Urea on the Inactivation of the Enzyme.

The enzyme sample, $0.05 \mathrm{mg} / \mathrm{ml}$ in $0,05 \mathrm{M}$ Tris- $\mathrm{HCl}$ buffer, pH 7.5 , containing $0.05 \%$ 2-mercaptoethanol was incubated at $25^{\circ} \mathrm{C}$ in the presence of various concentration of urea and samples were removed at the indicated times for measurement of residual activity.

$\bigcirc-\bigcirc, 1.0 \mathrm{M} ; \square-\square, 2.0 \mathrm{M} ; \triangle-\triangle, 4.0 \mathrm{M}$.

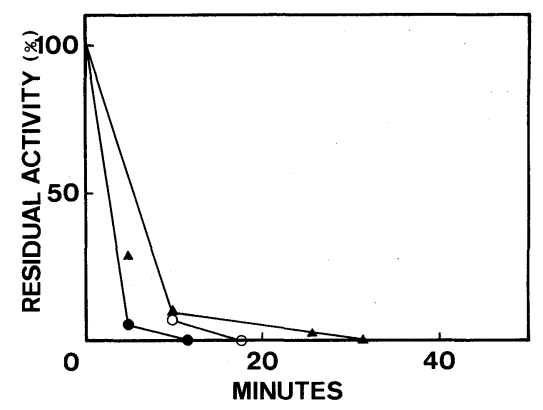

FIG. 7 Kinetics of Photoinactivation of the Enzyme.

The enzyme sample, $0.05 \mathrm{mg} / \mathrm{ml}$ in $0.05 \mathrm{M}$ Tris- $\mathrm{HCl}$ buffer, $\mathrm{pH} 7.5$, containing $0.05 \%$ 2-mercaptoethanol and $1 \mu \mathrm{M}$ Rose Bengal, was stirred and illuminated at $25^{\circ} \mathrm{C}$ with a 400 -W lamp placed $15 \mathrm{~cm}$ above the surface of the solution (55,000 lux).

- - no addition; $\bigcirc-\bigcirc, 0.3 \mathrm{~mm}$ NADP;

$0.3 \mathrm{~mm}$ 6-phosphogluconate.

$1 \mathrm{M}$ urea, being inactivated at higher molarities with a half-denaturation time of $5 \mathrm{~min}$ in $4 \mathrm{M}$ urea. The inactivation by urea was a first-order process.

\section{Photooxidation}

Exposure of the enzyme to low concentrations of Rose Bengal and light led to an irreversible loss of activity. As shown in Fig. 7, the addition of 6PG or NADP slightly protected the enzyme from this photo-inactivation and in all cases inactivation occurred as a biphasic process.

\section{DISCUSSION}

6-PGDH of Phormidium sp. was purified about 830 -fold. This is the first report of purification of the cyanobacterial 6PGDH to homogeneity. The molecular weight of the cyanobacterial 6PGDH was estimated to be 104,000 by gel filtration. The result of SDS polyacrylamide gel electrophoresis suggested that the enzyme consisted of two apparently identical subunits with a molecular weight of 52,000. The molecular weight of cyanobacterial enzyme is similar to those reported for the enzymes extracted from Candida utilis $(101,000),{ }^{1}$ Streptococcus faecalis $(108,000),{ }^{5)}$ Neurospora crassa $(110,000)^{3)}$ and rat liver $(112,000),{ }^{2)}$ but somewhat different from that of the enzyme from sheep liver $(94,000) .{ }^{4)}$ The enzymes, regardless of their sources, are dimers with subunits of equal molecular weight.

Cyanobacterial 6PGDH showed a sharp $\mathrm{pH}$ profile around $\mathrm{pH} 8$, distinct from the enzymes from Bacillus ${ }^{7)}$ and Streptococcus ${ }^{5)}$ which have broad $\mathrm{pH}$ profiles around $\mathrm{pH} 7.5$ to 8 . 6PGDH from Candida ${ }^{1)}$ and Bacillus ${ }^{7)}$ required $\mathrm{Mg}^{2+}$ ion for its full activity, while the cyanobacterial 6PGDH showed no $\mathrm{Mg}^{2+}$ requirement but was activated by $\mathrm{Mn}^{2+}$ and $\mathrm{Ca}^{2+}$.

The apparent $\mathrm{Km}$ values of cyanobacterial 6PGDH for NADP and 6-PG were of the same order of magnitude reported for the enzymes from other sources. Recently, Lubberding et al. ${ }^{17)}$ reported the results of a comparative study on the $K m$ for substrates and co-enzymes of the soluble enzymes G6PDH and 6PGDH in two closely related cyanobacteria, a mesophilic strain and a thermophilic strain. In the mesophilic strain the apparent $\mathrm{Km}$ values of $6 \mathrm{PGDH}$ are $9.0 \times$ $10^{-5} \mathrm{M}$ (substrate) and $2.5 \times 10^{-5} \mathrm{M}$ (NADP) and in the thermophilic strain they are $4.0 \times$ $10^{-5} \mathrm{M}$ (substrate) and $1.0 \times 10^{-5} \mathrm{M}$ (NADP). They suggested that, in general, thermophilic enzymes possess lower affinities for their substrates and co-enzymes than do mesophilic 
enzymes. Since the cyanobacterium Phormidium sp., which we used, shows an optimum growth temperature near $47^{\circ} \mathrm{C}$, the result that the apparent $\mathrm{Km}$ values of Phormidium 6PGDH for 6-phosphogluconate and NADP are $3.6 \times 10^{-5} \mathrm{M}$ and $1.3 \times 10^{-5} \mathrm{M}$, respectively, supports the above view.

Phormidium 6PGDH was markedly sensitive to sulfhydryl reagents, suggesting that a sulfhydryl groups may be involved in the active site of the enzyme. The enzyme was also protected from heat inactivation and photooxidation in the presence of the substrate and co-substrate. Similar results were reported for the enzymes from Bacillus, ${ }^{7}$ E. coli ${ }^{6}{ }^{6}$ and Neurospora $^{3)}$ but not for that from Candida. ${ }^{1)}$

The inhibition of cyanobacterial G6PDH by $\mathrm{NADPH}_{2}$ and ATP, and by RUBP, an intermediates of the Calvin cycle has been reported. ${ }^{9 \sim 11)}$ Phormidium 6 PGDH was also inhibited by RUBP, ribulose 5-P, $\mathrm{NADPH}_{2}$, and ATP, but in less degree than that of G6PDH. ${ }^{11)}$ Similar inhibition of 6PGDH by the intermediates of the Calvin cycle was reported by Lubberding et al. ${ }^{17)}$ Although these intermediates can affect the activity of the G6PDH and the 6PGDH, and can individually regulate these enzymes to some extent, they cannot be responsible for the total deactivation of the enzyme activities observed in the light. It is likely that a substantial regulation of the oxidative pentose phosphate pathway during photosynthesis would require the concerted action of several regulating factors.
Acknowledgments. This work was supported in part by a Grant-in-Aid for Encouragement of Young Scientists (No. 59760069) from the Ministry of Education, Science and Culture of Japan.

\section{REFERENCES}

1) M. Rippa, C. Picco and S. Pontremoli, J. Biol. Chem., 245, 4981 (1970).

2) D. Procsal and D. Holten, Biochemistry, 11, 1310 (1972).

3) W. A. Scott and T. Abramsky, J. Biol. Chem., 248, 3535 (1973).

4) M. Silverberg and K. Dalziel, Eur. J. Biochem., 38, 229 (1973).

5) R. B. Bridges, M. P. Palumbo and C. L. Wittenbreger, J. Biol. Chem., 250, 6093 (1975).

6) F. M. Veronese, E. Boccu and A. Fontana, Biochemistry, 15, 4026 (1976).

7) F. M. Veronese, E. Boccu and A. Fontana, Methods Enzymol., 89, 282 (1982).

8) R. Y. Stanier and G. Cohen-Bazire, Annu. Rev. Microbiol., 31, 225 (1977).

9) A. Grossman and R. E. McGowan, Plant Physiol., 55, 658 (1975).

10) R. A. Pelroy, R. Rippka and R. Y. Stanier, Arch. Microbiol., 87, 303 (1972).

11) F. Schaeffer and R. Y. Stanier, Arch. Microbiol., 116, 9 (1978).

12) H. Ochiai, H. Shibata, Y. Sawa and T. Katoh, Proc. Natl. Acad. Sci. U.S.A., 77, 2442 (1980).

13) O. H. Lowry, N. J. Rosebrough, A. L. Farr and R. J. Randall, J. Biol. Chem., 193, 265 (1951).

14) W. Heyns and P. DeMoor, Biochim. Biophys. Acta, 35, 1 (1974).

15) B. J. Davis, Ann. N. Y. Acad. Sci., 121, 404 (1964).

16) U. K. Laemmli, Nature, 227, 680 (1970).

17) H. J. Lubberding and P. V. M. Bot, Arch. Microbiol., 137, 115 (1984). 